\title{
KARAKTERISTIK PENGGUNA RUANG TERBUKA PUBLIK PADA TAMAN KOTA DI PALEMBANG
}

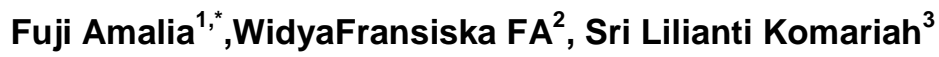 \\ ${ }_{1,2,3}$ Program Studi Arsitektur, Fakultas Teknik, Universitas Sriwijaya \\ Jalan Raya Palembang - Prabumulih Km. 32 Indralaya, OI, Sumatera Selatan, 30662 \\ *Fujiamalia@ft.unsri.ac.id
}

Diterima: 25-09-2020 Direview : 01-12-2020 Direvisi : 17-12-2020 Disetujui: 09-01-2021

ABSTRAK. Ruang terbuka publik digunakan masyarakat kota untuk melakukan kegiatan sosialisasi. Taman kota merupakan salah satu elemen perkotaan yang memberikan pelayanan spasial pada masyarakat dan meningkatkan kualitas lingkungan kota. Pelayanan ruang kota yang berkualitas adalah pelayanan yang dapat memberikan kenyamanan dan memenuhi kebutuhan pengguna ruang. Dengan kenyataan ini maka perlu dilakukan studi untuk melihat karaktersitik pengguna yang akan menjadi pedoman pengembangan ruang terbuka pada Taman kota yang sesuai dengan karakter pengguna. Metode kualitatif ini dilakukan untuk mengetahui karakteristik pelaku kegiatan pada setting ruang taman kota dengan mengandalkan survei pengamatan di lapangan. Lalu hasil survei dikompilasi dengan analisis deskriptif untuk melihat karakter pengguna antar Taman kota. Fokus penelitian terdapat pada karakter pengguna ruang terbuka publik pada taman kota. Hasil penelitian menyatakan bahwa karakter pengguna dan jenis kegiatan dipengaruhi oleh karakter fisik taman yaitu berupa lokasi, setting ruang, elemen pendukung taman dan sistem keamanan serta karakter non-fisik terkait dengan peraturan dalam penggunaan taman. Ruang terbuka publik yang memberikan kenyamanan terhadap pengguna adalah terdapat banyak teduhan, pedestrian yang baik, tempat duduk, arena bermain anak, tempat jualan makanan dan kondisi taman yang terawat. Karakter pengguna pada taman kota sangat beragam mulai dari anak- anak, remaja hingga dewasa dimana alasan utama datang ke taman adalah untuk refreshing, makan dan berolahraga.

Kata kunci:Karakteristik, ruang terbuka publik, taman kota

ABSTRACT. Public open space is an essential requirement for a society, which functions as a place to do socialization activity. A city park is one of the urban design elements that provide spatial services to the community and improve the quality of the city environment. Good quality city space services can provide comfort and meet the needs of space users. With this fact, it is necessary to conduct research to observe users' characteristics in physical setting space at city parks that will guide the development of city parks according to the user's character. The physical character spatial observation will be compiled with descriptive analysis to find the users' character In city parks. The research focuses on the users' character of the public open space in city parks. The result showed that the park's characteristic, which includes the location, the setting of space, the elements support of park and security system affect the users' character. Indicators of public open space provide comfort to users: there is a lot of shade in the vegetation, good pedestrian, seating, children's playground, where to sell food, and well-maintained garden conditions. The variety of User characters in city parks ranging from teenagers, adults to families, found a tendency to interest users to come to the park to refreshing, eating and exercising.

Keywords: characteristic, public open space, city park

\section{PENDAHULUAN}

Keberadaan ruang terbuka publik merupakan kebutuhan yang sangat diperlukan masyarakat dalam perkotaan, dimana ruang terbuka publik digunakan masyarakat kota untuk melakukan kegiatan sosialisasi. Dalam perancangan kota, ruang terbuka publik dan ruang terbuka hijau merupakan salah satu elemen yang penting. Ruang terbuka publik sangat diperlukan karena porsinya yang semakin berkurang pada lingkungan kota, padahal keberadaaanya secara tidak langsung mempengaruhi karakter dan budaya masyarakat di perkotaan (Noor et al., 2018).

Taman kota merupakan salah satu wadah yang memberikan pelayanan spasial pada masyarakat dan meningkatkan kualitas lingkungan kota karena taman kota berfungsi sebagai ruang terbuka hijau dan ruang terbuka publik yang memberikan sarana 
beraktifitas dan berinteraksi bagi masyarakat. Taman kota harus terintegrasi antara lingkungan, masyarakat, dan kesehatan melalui pendekatan fungsional dan lingkungan (Noor et al., 2018). Saat ini pesatnya pertumbuhan penduduk dan pembangunan terkadang tidak diimbangi dengan kebutuhan ruang terbuka publik yang sangat penting dalam suatu perencanaan dan perancangan suatu perkotaan, dimana sering terjadi alih fungsi lahan yang mengakibatkan turunnya kualitas lingkungan. Taman Kota menjadi bagian dari kebutuhan penduduk, dimana keberhasilan elemen ini memberikan pelayanan kota yang layak berkualitas dan berkelanjutan.

Perkembangan budaya masyarakat tak terlepas dengan space dan places dimana perilaku budaya dapat muncul dan terwujud dengan berbagai pola aktivitas pelakunya dalam sebuah setting ruang. Penggunaan secara sadar oleh masyarakat dapat memberikan implikasi yang luas terhadap keberadaan ruang terbuka, baik positif maupun negatif (Widaningsih, 2011). Taman kota sebagai setting ruang dan masyarakat sebagai pelaku aktifitas harus memiliki korelasi yang baik. Sehingga dalam perencanaan suatu taman kota perlu mengetahui karakteristik pengguna dan aktifitasnya. Oleh sebab itu untuk mewujudkannya, peran dan unsur masyarakat sebagai pengguna sangat diperlukan. Hal ini dikarenakan karakteristik dan pola perilaku pengguna nantinya akan mempengaruhi kebutuhan pengembangan ruang terbuka publik yang sesuai dengan masyarakat sebagai penggunanya. Pada penelitian ini kemudian dilakukan analisis mendalam terkait karakteristik pengguna pada taman kota Palembang yang sangat beragam.

keberhasilan dalam ruang terbuka publik bukan hanya dari karakteristik fisik ruang terbuka semata, akan tetapi manusia sebagai pengguna menjadi salah satu elemen yang tidak terlepas dari keberhasilan tersebut (Amalia et al., 2019). Hal ini selaras dengan penelitian yang sudah penulis lakukan sebelumnya dimana pengguna ruang terbuka publik yang cerdas dapat mendukung pelayanan publik yang berkualitas dan berkelanjutan. Taman kota saat ini belum memiliki manfaat dan kriteria sesuai dengan kebutuhan penggunanya (Budiyanti, 2014). Taman kota juga tidak bisa di duplikasi dari taman kota lainnya, akan tetapi harus memiliki karakter dan jati dirinya. Sehingga perlu dilakukan penelitian yang mengetahui karakteristik pengguna dan aktivitas dalam suatu ruang terbuka publik dimana kedepannyadapat menjadi acuan dalam pengembangan dan perancangan ruang terbuka publik yang merepresentasikan aspek lingkungan, kebutuhan masyarakat sebagai pengguna dan karakter kawasan.

\section{METODE PENELITIAN}

Dalam penelitian ini, penulis menggunakan beberapa literature dan jurnal- jurnal untuk mendukung penelitian, pertama mengenai taman kota sebagai ruang terbuka publik selanjutnya mengenai karakteristik fisik dan non- fisik serta karakter pengguna taman kota. Dari beberapa literatur tersebut, penulis mendapatkan variabel- variabel yang digunakan untuk turun ke lapangan. Berikut varibel yang digunakan untuk survei ke lapangan:

Tabel 1. Variabel Karakter Ruang Terbuka Publik Taman Kota

\begin{tabular}{|c|c|c|}
\hline No & Karakter & Variabel \\
\hline \multirow[t]{7}{*}{1} & Karakter & Landuse \\
\hline & fisik ( & Sirkulasi dan parkir \\
\hline & elemen & Pedestrian \\
\hline & kota) & Vegetasi (estetika dan \\
\hline & & tuduhan) \\
\hline & & Spot aktivitas \\
\hline & & signage \\
\hline \multirow[t]{9}{*}{2} & Karakter & Tempat sampah \\
\hline & Fisik & Tempat cuci tangan \\
\hline & (Elemen & Toilet \\
\hline & Penunjang & Musholla \\
\hline & ) & Arena Bermain \\
\hline & & Tempat duduk \\
\hline & & Fasilitas olaharaga \\
\hline & & Lampu \\
\hline & & security \\
\hline \multirow[t]{2}{*}{3} & Karakter & Peraturan terkait \\
\hline & Non- fisik & Fungsi Taman Kota \\
\hline
\end{tabular}

Tabel 2. Variabel Karakter Pengguna Ruang Terbuka Publik Taman Kota

\begin{tabular}{|c|c|c|}
\hline No & $\begin{array}{l}\text { Karakter } \\
\text { Pengguna }\end{array}$ & Variabel \\
\hline 1 & Jenis kelamin & $\begin{array}{l}\text { Laki- laki } \\
\text { Perempuan }\end{array}$ \\
\hline 2 & Umur & $\begin{array}{l}\text { Anak- anak } \\
\text { Dewasa } \\
\text { Lansia }\end{array}$ \\
\hline 3 & Pekerjaan & $\begin{array}{l}\text { Pedagang/wirausaha } \\
\text { lbu rumah tangga } \\
\text { Pelajar } \\
\text { Pns } \\
\text { Swasta } \\
\text { Lain - lain }\end{array}$ \\
\hline 4 & Moda transportasi & $\begin{array}{l}\text { Mobil } \\
\text { Motor } \\
\text { Transportasi publik } \\
\text { Pejalan kaki }\end{array}$ \\
\hline 5 & Intensitas & $\operatorname{Brp} x$ \\
\hline
\end{tabular}




\begin{tabular}{cll}
\hline & kunjungan & seminggu/sebulan \\
\hline 6 & Lama kunjungan & $<1,>1-2,>2-3$ \\
\hline 7 & Sosial interaksi & Sendiri \\
& & Bersama keluarga \\
& & Bersama teman \\
\hline 8 & Keramaian taman & Pagi \\
& (hari kerja dan & Siang \\
& hari libur) & Sore \\
& & Malam \\
\hline 9 & Alasan kunjungan & Olahraga \\
& & Bertemu teman \\
& & Mengisi waktu luang \\
& & Cari jajanan \\
& & Dekat rumah \\
& & Dekat temoat kerja \\
& & Kebeulan lewat \\
\hline 10 & Fungsi sebagai rtp & Taman kota \\
& & Tempat rekreasi \\
& & /wisata \\
& & Paru- paru kota \\
\hline 11 & Spot favorite & \\
& (alasan) & \\
\hline 12 & Rtp pada masa & Penggunaan masker \\
& pandemic & Jaga jarak \\
& & Menghindari \\
& & kerumunan \\
\hline Sumber : Analisa 2019 &
\end{tabular}

Menurut Sugiyono (2017), metode penelitian kualitatif adalah metode penelitian yang digunakan untuk meneliti pada kondisi objek yang alamiah, dimana peneliti adalah sebagai instrument kunci, teknik pengumpulan data dilakukan secara triangulasi, data yang diperoleh cenderung data kualitatif, analisis data bersifat induktif/kualitatif dan hasil penelitian kualitatif bersifat untuk memahami makna, memahami keunikan, mengkrontruksi fenomena, dan menemukan hipotesis. Oleh sebab itu penulis menggunakan metoda kualitatif deskriptif. Metode kualitatif ini dilakukan untuk mengetahui karakteristik ruang terbuka publik baik fisik maupun nonfisik dan pengguna ruang terbuka publik pada taman kota yang mengandalkan survei pengamatan di lapangan. Lalu hasil survei akan dikompilasi dengan analisa deskriptif karakter pengguna pada taman kota.

Lokus penelitian ini mengambil dua lokasi yang merupakan ruang terbuka publik yang berfungsi sebagai Taman Kota di Palembang. Taman kota Palembang yang di bahas dalam penelitian ini adalah taman Ampera dan taman POM IX Palembang.

\section{HASIL DAN PEMBAHASAN}

\section{Karakter fisik Ruang terbuka Publik Landuse}

Taman kota Ampera merupakan taman yang terletak di kawasan pusat kota, yang berada persis dibawah jembatan Ampera. Taman ini berada di antara icon- icon kota Palembang seperti jembatan Ampera, Monpera, Masjid agung, benteng KutoBesak dan bundaran air mancur. Fungsi bangunan (landuse) disekitar taman merupakan fungsi- fungsi komersial sehingga banyak yang melintasi taman kota ini walau hanya sekedar untuk duduk, foto- foto dengan latar Jembatan Ampera serta kawasan sekitar dan menunggu angkutan umum.

Taman kota POM IX TVRI merupakan taman yang terletak di jalan POM IX, Lorokpakjo, dimana ruang terbuka publik ini terletak di kawasan hunian. Selain itu taman ini juga terletak di dekat Gedung Stasiun TVRI Palembang. Pelaku kegiatan pada ruang terbuka ini kebanyakan adalah warga yang bermukim disekitar taman kota.

\section{Sirkulasi dan parkir}

Dari hasil pengamatan, untuk pencapaian taman Ampera dapat dikategorikan mudah karena berada di akses jalan besar dan dilewati oleh kendaraan umum. Namun disekitar taman sering terjadi kepadatan kendaraan karena sirkulasinya merupakan jalur yang sama menuju Pasar 16 ilir dan Benteng Kuto Besar. Sirkulasi pejalan kaki (pedestrian) sifatnya menerus dikawasan tersebut, sehingga memberikan kenyamanan bagi pelaku yang berjalan kaki. Untuk parkir memang tidak terdapat area parkir khusus, sehingga untuk ke taman ini pengunjung memarkirkan kendaraan di masjid agung, parkiran BKB atau parkiran pasar 16 sehingga pengunjung harus berjalan kaki untuk menuju taman. Tidak jarang juga pengendara motor memarkirkan kendaraanya di bahu jalan sehingga mengganggu pemandangan taman.

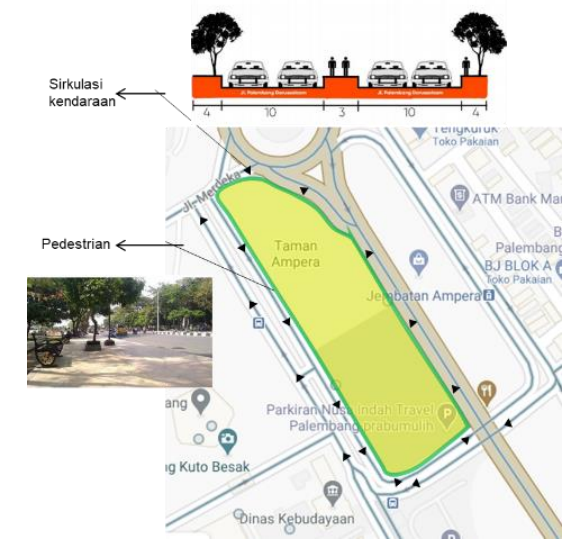

Gambar 1. Sirkulasi Kendaraan dan Pejalan Kaki di Taman Ampera

(Sumber: Dokumentasi Pribadi, 2020)

Taman POM IX TVRI untuk pencapaian juga berada di jalan besar, akan tetapi kondisi lalu 
lintasnya sangat ramai. Hal ini dikarenakan jalur menuju taman sama dengan jalur kendaraan menuju Palembang Square (mall) dan Rumah Sakit Siloam. Jalur pedestrian di dalam dan diluar taman sifatnya menerus juga dalam kondisi baik dan telah didesain khusus difable sehingga pejalan kaki merasa nyaman. Terdapat area parkir khusus untuk taman ini sehingga untuk parkiran dapat dikategorikan rapi.

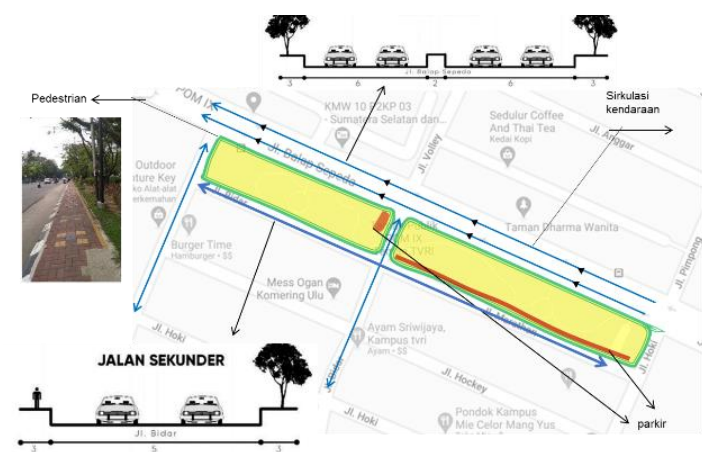

Gambar 2. Sirkulasi Kendaraan dan Pejalan Kaki di Taman POM IX TVR

(Sumber: Dokumentasi Pribadi, 2020)

\section{Vegetasi}

Pada taman kota Ampera dan taman POM IX TVRI terdapat vegetasi yang berfungsi sebagai peneduh dan estetika taman. Vegetasi yang berfungsi sebagai setetika taman masih terjaga dan terawat di taman ini, begitu juga vegetasi berupa peneduhan sangat banyak dan mampu memberikan kenyamanan bagi pengunjung. Spot yang terdapat banyak vegetasi menjadi spot favorit pengunjung taman


Gambar 3. Gambar Vegetasi Teduhan Pada Taman Dilihat Dari Peta Satelit (Sumber: Google Map, 2020)

Pada taman Ampera terdapat aktifitas pendukung yaitu area bermain skateboard. Area ini menjadi spot kumpul komunitas skateboard terutama pada pagi dan sore hari. Terdapat juga arena bermain anak akan tetapi fasilitasnya tidak terawat, ada beberapa arena bermain anak yang sudah tidak layak pakai, sehingga sedikit sekali anak- anak atau pengunjng yang bermain pada spot tersebut. Untuk komersialnya terdapat pedagang kaki lima yang berjualan makanan serta menjual jasa pangkas rambut.
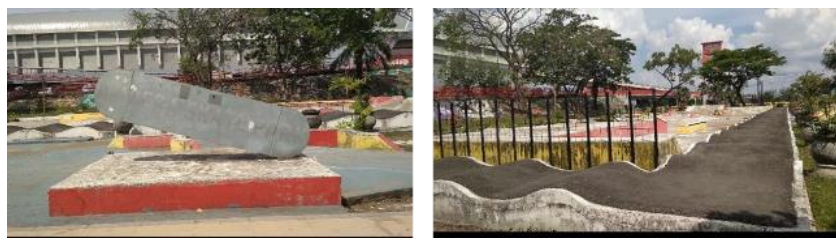

Gambar 4. Gambar Aktifitas pendukung di Taman Ampera

(Sumber: Dokumentasi pribadi, 2020)

Pada taman POM IX TVRI aktivitas yang menonjol adalah area bermain anak yang didukung dengan fasilitas bermain yang cukup lengkap dan terawat, selain itu terdapat juga tempat lapangan bulu tangkis yang aktif digunakan oleh pengguna taman. Dapat dikatakan arena bermain anak dan lapangan bulu tangkis menjadi salah satu pengunjung datang ke taman ini. Pada area taman ini juga terdapat spot khusus bagi ojek online, sehingga taman ini juga dimanfaatkan sebagai ruang tunggu transportasi umum online. Terdapat pedagang yang berjualan makanan menggunakan mobil pribadi, aktifitas ini juga menjadi aktifitas yang menjadi alasan pengguna datang.
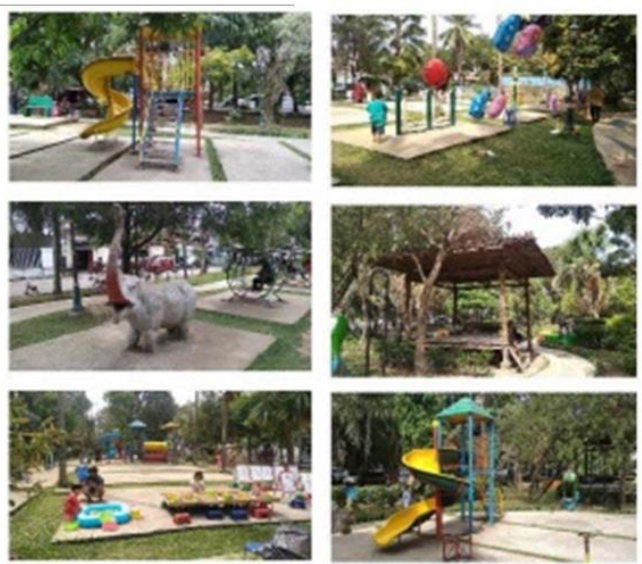

Gambar 5. Gambar Aktifitas pendukung di Taman POM IX TVRI

(Sumber: Dokumentasi pribadi, 2020)

\section{Elemen penunjang ruang terbuka publik}

Taman Ampera merupakan taman kota yang letaknya strategis di pusat kota, sehingga tanpa harus beraktifitas didalamnya, taman ini akan dilewati terutama pejalan kaki ketika menuju pasar 16, BKB, dan kawasan sekitarnya. Taman Ampera sendiri belum didukung dengan fasilitas kotak sampah, sehingga banyak sekali sampah plastik di area taman. Sebagai ruang publik, taman ini juga 
tidak memiliki fasilitas toilet umum ataupun tempat cuci tangan, sehingga dibeberapa spot terdapat bau yang tidak sedap, bahkan beberapa ketika kelapangan terlihat anak kecil buang air kecil sembarangan di taman ini. Selain mengganggu pengunjung hal ini juga merusak kualitas lingkungan taman. Fasilitas tempat duduk pada taman Ampera dalam kondisi baik dan didukung dengan pohon peneduh sehingga memberikan rasa nyaman, tetapi terkadang banyak terdapat sampah dan tempat duduk menjadi kotor. Selain itu sangat disayangkan di ruang publik seperti itu tidak terdapat petugas keamanan sehingga beberapa pengunjung mengatakan takut untuk berkunjung karena adanya preman- preman taman yang meminta- minta uang kepada pengunjung secara paksa. Selain itu banyak terdapat tukang parkir liar di sekitar taman, sehingga membuat pengunjung harus parkir jauh dari taman. Taman ini didukung dengan penerangan malam, sehingga memberikan kenyamanan bagi pengunjung taman.

Taman POM IX TVRI merupakan taman kota yang letaknya di pusat keramaian ,disekitar taman banyak terdapat fasilitas seperti pemukiman warga, drive tru Bank Sumsel Babel, kantor TVRI dan LumbanTirta. Sehingga banyak sirkulasi masyarakat disana baik pejalan kaki maupun yang memakai kendaraan.Pada taman POM IX TVRI terdapat fasilitas tempat sampah, selain itu tim kebersihan sampah membersihkan taman setiap pagi sehingga taman terlihat bersih dan nyaman bagi pengunjung. Taman tidak dilengkapi dengan toilet umum maupun tempat cuci tangan. Taman juga tidak terdapat petugas keamanan sehingga walau terdapat spot khusus parkir taman, masih terdapat tukang parkir dadakan yang memungut biaya dari pengunjung. Fasilitas tempat duduk dan pedestrian di ruang publik ini sangat terawat dan dalam kondisi baik. Didukung juga dengan adanya lampu taman pada taman dan pedestrian sehingga memberikan kenyamanan bagi pengunjung ketika malam hari.

Dari hasil pengamatan di lapangan, dapat dilihat elemen ruang terbuka publik di taman Ampera dan taman POM IX TVRI saat ini. Berikut tabel yang menjadi variabel dan indikator ketika melakukan survei, dimana yang dilihat adalah karakter ruang terbuka publik dan fungsi ruang terbuka. Dari karakter tersebut akan di analisa karakter pengunjung terhadap kondisi fisik dan non fisik ruang terbuka publik yang ada.
Tabel 3. Hasil Survei Lapangan Karakter Di TamanAmpera

\begin{tabular}{clll}
\multicolumn{3}{c}{ TamanAmpera } & \\
\hline $\mathbf{1}$ & Karakter & \multicolumn{1}{c}{ Variabel } & Kondisi \\
\hline & Karakter & Landuse & Oke \\
& elemen & Sirkulasi dan parkir & Kurang \\
& kota) & Pedestrian & Baik \\
& & Vegetasi (estetika & Baik \\
& & dan tuduhan) & \\
& & Spot aktivitas & Ada dan \\
& & Signage & baik \\
& & & Kurang \\
\hline $\mathbf{2}$ & Karakter & Tempat sampah & kurang \\
& Fisik & Tempat cuci tangan & tidak ada \\
& (Elemen & Toilet & tidak ada \\
& Penunjang & Musholla & tidak ada \\
& ) & Arena Bermain & kurang \\
& & Tempat duduk & Baik \\
& & Fasilitas olaharaga & Baik \\
& & Lampu & Baik \\
& & Security & kurang \\
\hline 3 & Karakter & Peraturan terkait & Tidak ada \\
& non- fisik & Fungsi taman : & \\
& & Taman & Baik \\
& & Kolam retensi & Tidak ada \\
& & Area rekreasi / & Baik \\
& & wisata & \\
& & Paru- paru kota & Cukup \\
& & &
\end{tabular}

Sumber : Analisa pribadi, 2020

Tabel 4. Hasil Survei Lapangan Karakter Fisik Di

\begin{tabular}{clll}
\multicolumn{4}{c}{ Taman POM IX TVRI } \\
\hline No & Karakter & \multicolumn{1}{c}{ Variabel } & \multicolumn{1}{c}{ Kondisi } \\
\hline $\mathbf{1}$ & Karakter & Landuse & Oke \\
& fisik ( & Sirkulasi dan parkir & Baik \\
& elemen & Pedestrian & Baik \\
& kota) & Vegetasi (estetika & baik \\
& & dan tuduhan) & \\
& & Spot aktivitas & Ada dan baik \\
& & signage & kurang \\
\hline $\mathbf{2}$ & Karakter & Tempat sampah & Baik \\
& Fisik & Tempat cuci tangan & Tidak ada \\
& (Elemen & Toilet & Tidak ada \\
& Penunjang & Musholla & Tidak ada \\
& ) & Arena Bermain & Baik \\
& & Tempat duduk & Baik \\
& & Fasilitas olaharaga & cukup \\
& & Lampu & Baik \\
& & security & Tidak ada \\
\hline 3 & Karakter & Peraturan terkait & Tidak ada \\
& non- fisik & Fungsi taman : & \\
& & Taman & Baik \\
& & Kolam retensi & Tidak ada \\
& & Area rekreasi / & Baik \\
& & wisata & \\
& & Paru- paru kota & baik \\
& & &
\end{tabular}

Sumber : Analisa 2020

Dari hasil pengamatan dilapangan dapat dilihat bahwa karakter ruang terbuka publik pada taman Ampera maupun taman POM dapat dikategorikan cukup baik, dan memberikan pengaruh di kawasan sekitarnya walaupun harus ada beberapa yang diperbaiki seperti 
toilet umum, tempat cuci tangan, tempat pembuangan sampah dan security system.

Dilihat dari kondisi non fisik, baik taman Ampera maupun taman POM belum memiliki aturan khusus dalam penggunaan taman, sehingga banyak pelanggaran yang dilakukan oleh pengguna taman. Sedangkan dilihat dari fungsinya, kedua taman merupakan ruang terbuka yang berfungsi sebagai taman, tempat rekreasi dan paru- paru kota

\section{Analisa karakter Pengguna dilihat dari karakter ruang terbuka publik}

Taman kota memiliki faktor internal yaitu karakteristik pengunjung dan aktvitasnya yang bertujuan untuk membuktikan kesesuaian Taman sebagai ruang sosial (Novitasari \& Navastara, 2017). Dalam melakukan analisis faktor internal tersebut diidentifikasi berdasarkan sosial-ekonomi dan pola kunjungan. Karakteristik sosial ekonomi dibagi berdasarkan usia, jenis kelamin, pekerjaan, dan tingkat pendapatan. Sedangkan karakteristik pola kunjungan dibagi berdasarkan pasangan interaksi, frekuensi kunjungan, jarak yang ditempuh, dan moda transportasi.

Taman Ampera yang berada di pusat kota Palembang, pengguna yang mendominasi adalah pengguna berjenis kelamin laki- laki yang mencapai $67 \%$ dengan usia produktif yang mencapai $64,51 \%$. Dimana prosentase pengguna nya disiangdan sore hari lebih tinggi, ketika pagi dan malam hari dapat dikatakan pengguna yang berkunjung taman Ampera walau lebih banyak laki- laki namun sudah mulai diimbangi dengan pengguna perempuan. Kondisi banyaknya preman di sekitar kawasan menjadi alasan pengguna laki laki lebih mendominasi. Berbeda dengan taman POM yang berada di dekat kawasan hunian, pengguna yang mendominasi adalah wanita 58\%. Prosentase di pagi dan sore hari lebih tinggi, di siang dan malam hari mulai diimbangi dengan pengguna laki- laki walau yang perempuan masih lebih tinggi. Hal ini dikarena lokasi taman yang berada dikawasan yang berbeda. Pada kawasan taman Ampera pengguna adalah orang- orang yang akan mengunjungi pasar, para pedagang, komunitas skateboard, dan pengguna yang kebetulan lewat ketika akan mengunjungi objek- objek di sekitar taman. Pada sore hari mulai ramai terutama pengunjung yang merupakan komunitas olahraga skateboard. Sedangkan taman POM lebih tinggi presentase pengguna wanita karena terletak di dekat kawasan hunian dengan kegiatan menemani anak, jalan- jalan, mencari jajanan. Taman ini didominasi oleh anak- anak juga, dikarenakan fasilitas bermain anak yang tertata rapi dan bersih sehingga pengunjung tidak ragu untuk datang ke taman.

Tabel 5. Persentase Karakter Pengguna Ruang Terbuka Publik di Taman Ampera

\begin{tabular}{|c|c|c|}
\hline $\begin{array}{l}\text { Karakter } \\
\text { pengguna }\end{array}$ & Variabel & Persentase \\
\hline Jenis & Laki - laki & $67 \%$ \\
\hline kelamin & Perempuan & $33 \%$ \\
\hline \multirow[t]{3}{*}{ Umur } & Anak - anak & $19,35 \%$ \\
\hline & Dewasa & $64,51 \%$ \\
\hline & Lansia & $16,14 \%$ \\
\hline \multirow[t]{6}{*}{ Pekerjaan } & Pedagang/wirausaha & $18,9 \%$ \\
\hline & Ibu rumah tangga & $20,2 \%$ \\
\hline & Pelajar/mahasiswa & $34,8 \%$ \\
\hline & Pns & $11,1 \%$ \\
\hline & Swasta & $12,2 \%$ \\
\hline & Lain- Lain & $2,8 \%$ \\
\hline \multirow{4}{*}{$\begin{array}{l}\text { Moda } \\
\text { transportasi }\end{array}$} & Mobil & $20,3 \%$ \\
\hline & Motor & $45,4 \%$ \\
\hline & Transportasi umum & $28,2 \%$ \\
\hline & Pejalan kaki & $6,1 \%$ \\
\hline \multirow{2}{*}{$\begin{array}{l}\text { Lama } \\
\text { kunjungan }\end{array}$} & $<1$ jam & $59 \%$ \\
\hline & $>1$ jam & $41 \%$ \\
\hline \multirow{3}{*}{$\begin{array}{l}\text { Sosial } \\
\text { interaksi }\end{array}$} & Sendiri & $17,39 \%$ \\
\hline & Bersama keluarga & $43,47 \%$ \\
\hline & Bersama teman & $39,14 \%$ \\
\hline \multirow{3}{*}{$\begin{array}{l}\text { Waktu } \\
\text { ramai }\end{array}$} & Pagi & $24,24 \%$ \\
\hline & Siang & $33,33 \%$ \\
\hline & Sore & $42,43 \%$ \\
\hline \multirow{5}{*}{$\begin{array}{l}\text { Alasan } \\
\text { kunjungan }\end{array}$} & Bertemu teman & $38,4 \%$ \\
\hline & $\begin{array}{l}\text { Bermain fasilitas } \\
\text { taman }\end{array}$ & $38,46 \%$ \\
\hline & Mengisi waktu luang & $7,86 \%$ \\
\hline & Cari jajanan & $11,55 \%$ \\
\hline & Kebetulan lewat & $3,84 \%$ \\
\hline \multirow[t]{4}{*}{ Spot favorit } & $\begin{array}{l}\text { Panggung } \\
\text { pementasan }\end{array}$ & $17,64 \%$ \\
\hline & Arena skethoard & $47,05 \%$ \\
\hline & Tempat permainan & \\
\hline & $\begin{array}{l}\text { anak dan tempat } \\
\text { duduk dibagian } \\
\text { tengah taman }\end{array}$ & $35,29 \%$ \\
\hline
\end{tabular}

Sumber : Analisa pribadi, 2020

Taman Ampera didominasi dengan pengunjung yang menggunakan motor $45 \%$, hal ini dikarenakan tidak ada parkir khusus serta padatnya parkiran yang ada di sekitar taman, letak taman yang ada dipusat kota yang terkadang macet sehingga pengguna merasa lebih efisiensi ketika menggunakan kendaraan bermotor. Rata- rata pengunjung adalah pengguna usia produktif. Ketika mengunjungi taman POM pengunjung di dominasi dengan pejalan kaki dan motor dengan prosentasi sama 30,6\%, hal ini dikarenakan lokasi dan fungsi yang ada disekitar kawasan hunian. Pada siang hari 
orang- orang yang di sekitar taman sering datang dengan berjalan kaki hanya untuk refreshing dan mencari jajanan ketika istirahat siang.

\begin{tabular}{|c|c|c|}
\hline $\begin{array}{l}\text { Karakter } \\
\text { pengguna }\end{array}$ & Variabel & Persentase \\
\hline Jenis & Laki - laki & $42 \%$ \\
\hline kelamin & Perempuan & $58 \%$ \\
\hline \multirow[t]{3}{*}{ Umur } & Anak - anak & $33,33 \%$ \\
\hline & Dewasa & $55,55 \%$ \\
\hline & Lansia & $11,12 \%$ \\
\hline \multirow[t]{8}{*}{ Pekerjaan } & Pedagang/wirausaha & $17,14 \%$ \\
\hline & Ibu rumah tangga & $21,42 \%$ \\
\hline & Pelajar/mahasiswa & $14,28 \%$ \\
\hline & Pns & $10,71 \%$ \\
\hline & Swasata & $17,85 \%$ \\
\hline & Ojek online & $9,28 \%$ \\
\hline & Tukang parkir & $3,57 \%$ \\
\hline & Petugas kebersihan & $5,57 \%$ \\
\hline \multirow{4}{*}{$\begin{array}{l}\text { Moda } \\
\text { transportasi }\end{array}$} & Mobil & $25,51 \%$ \\
\hline & Motor & $30,61 \%$ \\
\hline & Transportasi umum & $13,26 \%$ \\
\hline & Pejalan kaki & $30,62 \%$ \\
\hline \multirow{2}{*}{$\begin{array}{l}\text { Lama } \\
\text { kunjungan }\end{array}$} & $<1$ jam & $46 \%$ \\
\hline & $>1$ jam & $54 \%$ \\
\hline \multirow{3}{*}{$\begin{array}{l}\text { Sosial } \\
\text { interaksi }\end{array}$} & Sendiri & $14,28 \%$ \\
\hline & Bersama keluarga & $38,09 \%$ \\
\hline & Bersama teman & $46,82 \%$ \\
\hline \multirow{3}{*}{$\begin{array}{l}\text { Waktu } \\
\text { ramai }\end{array}$} & Pagi & $27,77 \%$ \\
\hline & Siang & $22,22 \%$ \\
\hline & Sore & $50,56 \%$ \\
\hline \multirow{6}{*}{$\begin{array}{l}\text { Alasan } \\
\text { kunjungan }\end{array}$} & Bertemu teman & $21,87 \%$ \\
\hline & Bermain fasilitas & $37,5 \%$ \\
\hline & taman & $12,5 \%$ \\
\hline & Mengisi waktu luang & $18,75 \%$ \\
\hline & Cari jajanan & $9,38 \%$ \\
\hline & Dekat rumah & 0 \\
\hline \multirow[t]{6}{*}{ Spot favorit } & Panggung & $7,81 \%$ \\
\hline & Bundaran taman & $23,43 \%$ \\
\hline & Arena bermain anak & $35,15 \%$ \\
\hline & Lapangan badminton & $13,76 \%$ \\
\hline & Gazebo & $7,81 \%$ \\
\hline & Shelter & $10,18 \%$ \\
\hline
\end{tabular}

Sumber : Analisa pribadi, 2020

Intensitas pengunjung taman Ampera yang konsisten adalah komunitas skateboard dimana bisa 2-3 kali per minggu ke taman. Beberapa pengguna yang diwawancari mengatakan bisa 2 kali perbulan ke taman tersebut karena awalnya mau jalan- jalan ke pasar 16 dan Benteng Kuto besar. Intensitas kunjungan di taman Ampera masih sangat beragam. Pengaruh letak ruang terbuka yang berada disekitar objek- objek wisata pusat kota juga mengurangi eksistensi taman Ampera. Lama kunjungan hampir 59\% tidak lebih dari 1 jam dengan alasan ke taman Ampera untuk dapat mendokumentasikan objek sekitar dimana ketika berada di taman Ampera view objek sekitar lebih jelas, berteduh setelah penat keliling di objek sekitar, menunggu keluarga berbelanja dan janjian bertemu dengan teman. Komunitas olahraga adalah pengguna dengan lama kunjungan lebih dari 1 jam. Berbeda dengan taman POM intensitas pengunjung 3 kali seminggu mencapai $32 \%$, lokasi yang berada dikawasan hunian, didukung fasilitas bermain anak yang rapi. Pengguna yang diwawancarai mengatakan kebutuhan akan ruang sosialisi, menghilangkan penat setelah seharian beraktifitas dan jajanan yang yang menarik pengguna ke taman. Lama kunjungan pengguna yang lebih dari 1 jam mencapai 54\% dengan kegiatan olahraga, permainan anak yang ada dilokasi, menjaga anak, santai berkumpul dengan teman, dan makan jajanan.

Pengguna taman Ampera mayoritas adalah remaja dan dewasa yang datang berkelompok, ada beberapa juga yang datang sendiri ke taman sekedar untuk menungu teman atau duduk santai main bermain game di handphone. Pada taman POM mayoritas adalah remaja, dewasa dan anak- anak. Pengguna banyak merupakan keluarga yang hendak olahraga, mencari jajanan, bertemu teman dan sekedar mengisi waktu luang. Pengguna berkegiatan bersama keluarga dan teman, hanya $14 \%$ yang datang sendiri ke taman dengan tujuan menghabiskan waktu luang ataupun ingin menghirup udara segara. Alasan pengunjung ke taman ini juga salah satunya karena kondisi pandemic covid- 19 ini, sehingga pengguna merasa lebih nyaman berada di ruang terbuka seperti taman.

Pengunjung taman Ampera ramai di pagi dan sore hari. Di pagi hari rata- rata pengguna adalah yang punya kepentingan ke pasar 16 sedangkan pada sore diramaikan oleh komunitas skateboard. Kegiatan hampir sama dengan hari kerja dan hari libur, hanya saja hari libur menjadi lebih ramai karena banyak pengunjung yang mendatangi objek wisata di sekitar taman. Pada siang hari pengguna berada di taman untuk berteduh di bawah pohon rindang dan duduk- duduk di pedestrian. Alasan teduhan yang nyaman menjadi alasan pengguna datang ke taman Ampera. Pada malam hari di hari libur pengguna tetap ramai kecuali di hari kerja banyak pengguna mengatakan takut pada malam hari kesana dengan alasan keamanan.

Pengunjung taman POM relatif ramai di pagi dan sore hari terutama di hari jumat, sabtu dan minggu. Pada siang hari banyak pengguna yang mengatakan waktunya istirahat dan 
kondisi cuaca yang panas membuat orang malas keluar rumah. Pada sore hari merupakan waktu teramai di taman ini. Pada hari libur sabtu dan minggu terdapat orang yang membuka lapak untuk anak- anak seperti mewarnai gambar dengan cat air dan permainan memancing ikan shingga meningkatkan jumlah pengunjung. Pengunjung remaja yang datang ke taman lebih dominan untuk mencari jajanan yang dijajakan di taman. Alasan teduhan, tempat jajanan dan terdapat tempat bemain anak- anak yang terjaga menjadi mayoritas tujuan pengguna.

Taman Ampera di kawasannya berfungsi sebagai taman kota di Palembang. Hal ini didukung dengan okupasi pengguna yang cenderung memilih spot di tengah taman yang terdapat tempat duduk dan teduhan. Selain itu juga pedestrian yang nyaman karena adanya teduhan seringkali digunakan pengguna sebagai spot untuk duduk- duduk santai. Selain itu spot area skateboard yang menjadi area favorite pengunjung, karena memang desainnya dibuat menarik bagi penggunanya.

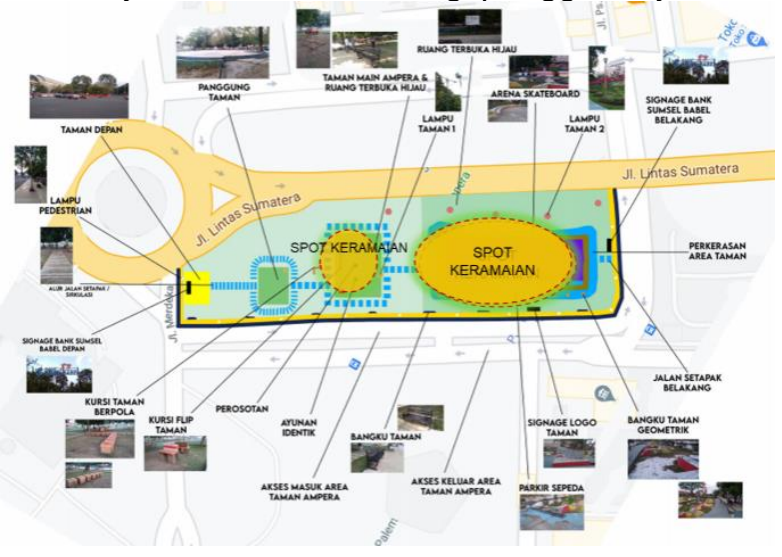

Gambar 6. Gambar Area Spot Keramaian di Taman Ampera

(Sumber: Dokumentasi pribadi, 2020)

Taman POM berfungsi sebagai taman kota, sama seperti taman Ampera area teduhan menjadi area pengguna di taman ini. Teduhan di taman POM terdiri dari pohon teduhan pada area tempat duduk dan gazebo. Area favorit pengguna berada ditengah taman karena ada fasilitas bermain anak dan tempat duduk dengan teduhan yang dapat digunakan untuk menunggu/ mengawasi anak yang sedang bermain. Gazebo menjadi spot favorite karena desain yang menarik selain itu ukurannya yang memang sesuai dengan pengguna yang cenderung datang bersama keluarga. Diikuti dengan area lapangan bulu tangkis dimana hampir setiap sorenya terdapat pengguna yang bermain disana, pada pagi hari area ini digunakan oleh ibu- ibu untuk senam. Spot yang terdapat banyak jajanan menjadi area bersantai pengguna taman di sore hari. Spot area teduhan di ujung taman menjadi area yang sering dikunjungi dar pagi sampai malam, hal ini dikarenakan spot itu digunakan para ojek online sebagai shelter mereka. Hampir seluruh spot di taman ini menjadi area favorit.

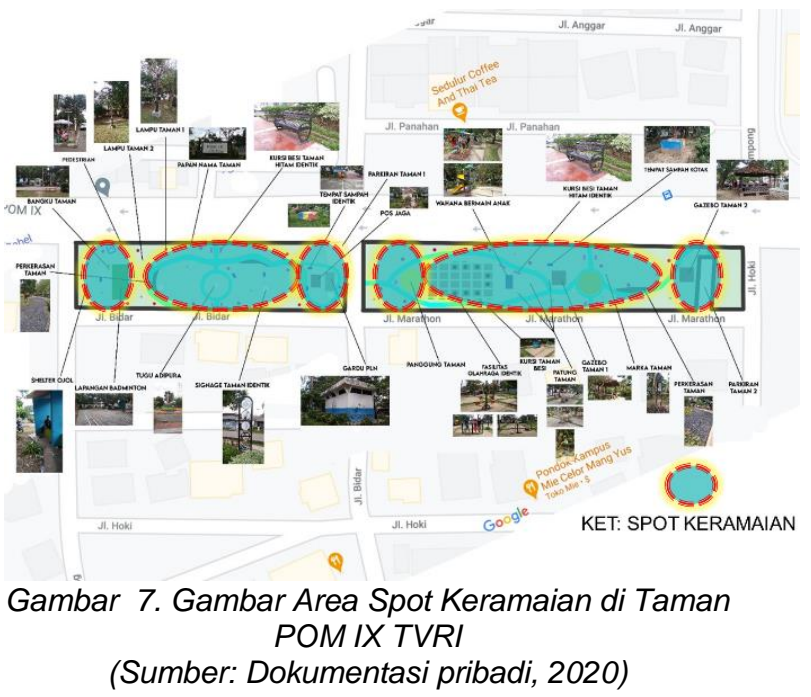

Dari hasil analisa karakter ruang terbuka dan pengguna ruang terbuka di atas, dapat dilihat beberapa persamaan dan perbedaan antara taman Ampera dan Taman POM IX TVRI. Berikut matrik hasil analisa kedua taman dapat dilihat pada tabel berikut:

Tabel 7. Hasil analisa karakter ruang terbuka dan pengguna pada taman Ampera dan taman POM

\begin{tabular}{ll}
\hline $\begin{array}{l}\text { Karakter } \\
\text { pengguna }\end{array}$ & \multicolumn{1}{c}{$\begin{array}{c}\text { Hasil analisa karakter ruang } \\
\text { terbuka dan pengguna pada } \\
\text { taman Ampera dan taman POM }\end{array}$} \\
\hline $\begin{array}{l}\text { Jenis } \\
\text { kelamin }\end{array}$ & $\begin{array}{l}\text { Pengunjung laki- laki dominan } \\
\text { karena faktor keamanan di Taman }\end{array}$ \\
& $\begin{array}{l}\text { Ampera, sedangkan di Taman POM } \\
\text { perempuan yang dominan karena } \\
\text { fasilitas pendukung yang ada di } \\
\text { taman }\end{array}$ \\
\hline Umur & $\begin{array}{l}\text { Anak- anak dan dewasa merupakan } \\
\text { rata- rata umur pengunjung pada } \\
\text { kedua taman }\end{array}$ \\
\hline Pekerjaan & $\begin{array}{l}\text { lbu rumah tangga dominan di } \\
\text { Taman POM sedangkan pada }\end{array}$ \\
& $\begin{array}{l}\text { Taman Ampera dominan } \\
\text { pengunjung adalah } \\
\text { pelajar/mahasiswa }\end{array}$ \\
\hline Moda & $\begin{array}{l}\text { Pengguna di kedua taman dominan } \\
\text { menggunakan moda transportasi }\end{array}$ \\
\hline Lama & motor \\
kunjungan & $\begin{array}{l}\text { Lebih lama kunjungan Taman POM } \\
\text { karena arena bermain anak yang } \\
\text { terawat, sedangkan pada Taman }\end{array}$ \\
& $\begin{array}{l}\text { Ampera pengunjung lebih sering } \\
\text { datang karena lewat di sekitar } \\
\text { taman }\end{array}$ \\
\hline
\end{tabular}




\begin{tabular}{|c|c|}
\hline $\begin{array}{l}\text { Sosial } \\
\text { interaksi }\end{array}$ & $\begin{array}{l}\text { Berkumpul bersama keluarga dan } \\
\text { teman sama- sama dominan di } \\
\text { kedua taman, Taman POM lebih } \\
\text { banyak karena arena bermain anak, } \\
\text { spot banyak teduhan dan lokasi di } \\
\text { sekitar hunian sedangkan pada } \\
\text { Taman Ampera melakukan } \\
\text { sosialisasi bersama keluarga dan } \\
\text { teman karena lokasi disekitar } \\
\text { kawasan sejarah dan banyak spot } \\
\text { teduhan }\end{array}$ \\
\hline $\begin{array}{l}\text { Waktu } \\
\text { ramai }\end{array}$ & $\begin{array}{l}\text { Kedua taman sama-sama sering } \\
\text { dikunjungi pada sore hari }\end{array}$ \\
\hline $\begin{array}{l}\text { Alasan } \\
\text { kunjungan }\end{array}$ & $\begin{array}{l}\text { Alasan berkunjung pada kedua } \\
\text { taman adalah menggunakan } \\
\text { fasilitas taman yang ada dimana di } \\
\text { Taman POM dominan dengan } \\
\text { arena bermain anak, sedangkan } \\
\text { Taman Ampera adanya tempat } \\
\text { bermain skateboard }\end{array}$ \\
\hline Spot favorit & $\begin{array}{l}\text { Pada kedua taman arena bermain } \\
\text { anak merupakan spot favorit } \\
\text { pengunjung karena kebutuhan } \\
\text { anak- anak akan rekreasi di luar } \\
\text { ruang }\end{array}$ \\
\hline
\end{tabular}

Sumber : Analisa pribadi, 2020

Masa pandemik ini menjadikan pengamatan tersendiri terhadap pengguna ruang terbuka. Pengguna yang datang ke taman Ampera dan taman pom rata- rata menggunakan masker kain. Fenomena lainnya yang didapat dari penjaga kebersihan taman, kunjungan ke taman Ampera dan taman POM justru meningkat disaat pandemic ini. Alasan pengunjung adalah mereka merasa lebih nyaman berada ruang terbuka publik seperti taman dibandingkan bepergian ke tempat hiburan lain seperti mall, kolam renang, ataupun rumah makan. Kejenuhan selalu berada di rumah selama masa pandemic menjadikan kebutuhan akan ruang terbuka publik meningkat terutama yang terdapat teduhan, area bermain anak, fasilitas olahraga dan area- area kuliner. Mayoritas pengguna tidak dapat mematuhi protokol kesehatan yang harus menjaga jarak (physical distancing) ketika berkegiatan di luar rumah. Taman Ampera dan taman POM belum terdapat fasilitas cuci tangan dan handsanitizr dimana dalam kondisi pandemic merupakan fasilitas yang harus tersedia di ruang publik. Namun kesadaran akan protokol kesehatan akan penggunaan masker. Pada taman Ampera pengunjung yang menggunakan masker mencapai $87 \%$, pengguna taman yang merupakan pedagang disana yang justru tidak memakai masker sedangkan hanya $49 \%$ pengunjung yang membawa handsanitizer. Berbeda dengan taman POM $79 \%$ pengguna membawa handsanitizer dengan alasan protokol kesehatan, selain itu pengguna taman
$88 \%$ mayoritas menggunakan masker selama di taman.

\section{KESIMPULAN}

Dari hasil pengamatan yang dilakukan pada dua taman kota dipalembang, didapat bahwa karakter fisik ruang terbuka publik mempengaruhi karakter pengguna. Baik taman Ampera dan Taman POM IX TVRI memiliki karakteristik fisik spasial yang cukup baik. Karakter pengguna dan jenis kegiatan dipengaruhi oleh karakter fisik taman yaitu berupa lokasi, setting ruang, elemen pendukung taman dan sistem keamanan. Selain itu faktor non- fisik seperti peraturan dalam penggunaan taman juga mempengaruhi pengguna terutama dimasa pandemic seperti saat ini.

Ruang terbuka publik yang memberikan kenyamanan terhadap pengguna adalah terdapat banyak teduhan, pedestrian yang baik, tempat duduk, arena bermain anak, tempat jualan makanan dan kondisi taman yang terawat. Karakter pengguna pada taman kota sangat beragam mulai dari anak- anak, remaja hingga dewasa dimana alasan utama datang ke taman adalah untuk refreshing, mencari jajanan dan berolahraga.

Karakter pengguna baik taman Ampera maupun taman POM menyukai karakter taman yang terdapat teduh, bersih dan didukung dengan fasilitas penunjang yang baik. Mayoritas pengguna taman adalah mereka yang ingin menghilangkan rasa penat, membutuhkan ruang yang nyaman untuk bersosialisi. Fasilitas bermain anak dan olahraga merupakan spot yang menarik pengguna untuk datang ke taman.

Lokasi suatu ruang publik juga mempengaruhi karakteristik sosial ekonomi pengguna. Dimana kecenderungan pengguna ke taman bersama keluarga sedangkan lokasi yang berada di sekitar kawasan komersial dan objek wisata selain bersama keluarga, pengguna lebih dominasi berkumpul dengan temantemannya. Lokasi taman yang berada di kawasan hunian dan dilengkapi dengan fasilitas penunjang taman yang baik akan dikunjungi pengguna dengan intesintas 2-3 kali seminggu. Berbeda dengan lokasi taman yang berada di kawasan komersial dan objek wisata disekitarnya, rata- rata pengunjung datang dengan intensita 1-2 kali sebulan.

Karakter pengguna yang beragam di ruang publik, maka sistem keamanan, kebersihan 
dan elemen pendukung seperti signage diperlukan pada ruang terbuka publik. Signage sebagai penanda atau pemberi informasi pada ruang terbuka akan mempengaruhi perilaku pengguna. Misal dalam kondisi pandemik seperti saat ini, ada papan peringatan mengenai kewajiban memakai masker dan menjaga jarak, maka pengguna akan merasa tidak nyaman saat tidak mematuhi peraturan dalam menggunakan ruang publik.

Karakter pengguna yang menggunakan ruang terbuka publik sebagai tempat menghilangkan penat, berolahraga, dan mencari jajanan mempengaruhi waktu kegiatan juga. Waktu yang paling ramai kunjungan ke taman adalah ketika hari libur (sabtu, minggu) dengan kecenderungan periode waktu pada pagi atau sore hari. Kualitas ruang seperti teduhan, kebersihan dan keamanan menentukan lama durasi pengguna berada di taman, semakin lama keberadaan pengguna maka taman bisa dikatakan sebagai ruang publik yang sesuai dengan kebutuhan penggunanya.

Pengembangan taman kota sebagai ruang terbuka publik harus dapat memenuhi kebutuhan pengguna. Sehingga diharapkan pengguna dapat memberikan implikasi yang positif terhadap keberadaan ruang terbuka. Taman kota sebagai setting ruang dan pengguna taman sebagai pelaku aktifitas harus memiliki korelasi yang baik sehingga tercipta lingkungan dan masyarakat yang berkualitas.

\section{UCAPAN TERIMA KASIH}

Peneliti mengucapkan terima kasih kepada semua pihak yang telah membantu dalam proses penulisan dan penyelesaian penelitian ini. Secara khusus peneliti mengucapkan terima kasih kepada instansi Universitas Sriwijaya Palembang yang telah memberikan konstribusi dana Anggaran DIPA Badan Layanan Umum Universitas Sriwijaya tahun anggaran 2020 kepada peneliti sehingga penelitian ini dapat diselesaikan dengan lancar dan tepat waktu.

Nomor Surat Kontrak Penelitian 0648/ UN9/ SK.BUK.KP/2020

\section{DAFTAR PUSTAKA}

Amalia, F. ... Drastiani, R. (2019). Kajian Pengembangan Konsep Smart City, Ditinjau Dari Elemen Ruang Terbuka
Publik (Studi Kasus: Kambang Iwak Dan Kolam Retensi Jakabaring). Palembang.

Budiyanti, R. B. (2014). Manfaat Taman Kota Sebagai Rona Kegiatan Publik. Institut Teknlogi Bandung.

Noor, A. ... Ischak, M. (2018). Karakter Pengguna Ruang Publik Di Taman Ayodya Jakarta Selatan. Jurnal Penelitian Dan Karya IImiah Arsitektur Usakti, 16(02), 60. https://doi.org/10.25105/agora.v16i02.32 29

Novitasari, D. F., \& Navastara, A. M. (2017). Karakteristik Pengunjung dan Aktivitasnya Ruang Sosial di Taman Keplaksari Kabupaten Jombang. Teknik ITS, 6(2), 2337-3520.

Sugiyono. (2017). Metode Penelitian Kuantitatif, Kualitatif, dan R\&D. Bandung: CV Alfabeta.

Widaningsih, L. (2011). Ruang Publik Kota Sebagai " Places" Dalam Mengembangkan Aktivitas Berkebudayaan Masyarakat Perkotaan. 1-9. Retrieved from http://file.upi.edu/Direktori/FPTK 